VILAÇA, Aparecida. 2006. Quem somos nós: os Wari' encontram os brancos. Rio de Janeiro: EdUFRJ. 608 pp.

\section{Christina Osward}

Doutoranda PPGAS/MN/UFRJ

Como uma tese de doutorado com mais de 600 páginas, de inspiração estruturalista, transforma-se em um livro de leitura extremamente agradável, daqueles que não se consegue largar, que se carrega debaixo do braço para os lugares mais estranhos, como um bom romance? Durante vinte anos, Aparecida Vilaça, sob a orientação de Eduardo Viveiros de Castro, trabalhou (e ainda trabalha) junto aos Wari', povo falante da língua da família txapakura, cujas aldeias se acham no estado de Rondônia. Neste contexto, destaca-se a relação da antropóloga com Paletó que, ao adotá-la como filha ["não somos parentes de mentira" (:19), ele costuma dizer], inseriu-a em uma generosa rede de informações. O resultado desse duplo convívio, digamos, na Academia e no campo, pode ser notado na precisão da seleção dos dados que resultaram na construção das questões apresentadas sem subterfúgios na introdução: "Por que, afinal, decidiram viver junto dos brancos? E por que dizem que estão, eles mesmos, virando brancos?" (:51)

Nada está ali por acaso. A análise da constituição dos subgrupos wari', que dá início ao livro, constitui o pano de fundo para a compreensão dos demais problemas que surgem ao longo da narrativa. Se há sempre uma distância entre aquilo que um autor diz que vai fazer e o que ele realmente faz, Vilaça foge a essa regra. Assim, a superposição dos títulos dos capítulos das partes I e II contribuiu, de fato, para o bem-amarrado da obra. Da mesma forma que a constituição dos subgrupos, a descrição das festas, das guerras e das cronologias da primeira parte é retomada e acionada adiante, tanto na parte II - dedicada à análise de um conjunto de mitos wari' sobre a alteridade, dentre os quais está o mito de origem do branco - como na parte III, que narra o episódio no qual a "pacificação" (conceito, aliás, à espera de um termo mais adequado) se efetivou.

No final do livro, encontram-se diversos apêndices: genealogias, dados demográficos, informações sobre terras, localização dos rios e das roças, e um grande mapa que retrata as áreas ocupadas pelos Wari' nas diferentes décadas do século $\mathrm{XX}$, materiais que ajudam a localizar os eventos históricos narrados.

Um outro aspecto também contribui para a "leveza" do livro, que é, no entanto, densamente teórico: a articulação entre a teoria e a prática, ou melhor dizendo, a teoria não está confinada na introdução e na conclusão - esta última aliás, sequer existe - mas distribuída de forma a dar consistência aos argumentos e unidade às questões. Na verdade, leveza talvez não seja um bom adjetivo para qualificar o livro. Melhor seria precisar a sua "delicadeza", conquista de antropólogos que não invadem a privacidade alheia e, conseqüentemente, não causam constrangimento ao leitor. Além disso, pode-se dizer que a extensão do livro é suplantada pela intensidade com que a alteridade wari' nos é apresentada.

O livro narra as incessantes transformações ou metamorfoses wari' e analisaas de acordo com o modelo analítico teórico da "economia simbólica da alteridade". Neste sentido, elas poderiam ser descritas como traçando o percurso que começa em estado geral de meta-afinidade e que, na história, busca estabelecer relações de consangüinidade. Como afirma Vilaça: "Os Wari' procuram a todo custo, no diaa-dia, transformar a afinidade em consangüinidade" (:105). No entanto, tal como 
mostrou Viveiros de Castro a propósito da construção do parentesco amazônico, trata-se de um movimento que encompassa o sentido contrário. Ele depende, portanto, da perspectiva escolhida para servir como ponto de partida. Por isso, como Vilaça apresenta a história wari' em relação aos brancos, a direção que surge é a da afinização, na qual subjaz o princípio de isometria.

Em um mundo anímico (Descola) que inclui animais, xamãs e espíritos, a teoria perspectivista de Viveiros de Castro e T. Stolze Lima é utilizada para responder às questões já mencionadas sobre o virarbranco. Elas envolvem a definição mesma de humanidade. Afinal, qual são as diferenças entre o homem e o animal? Questão relevante aberta a propósito da etnografia wari' que, se analisada, nos conduz a colocar em xeque outras certezas.

Como notou Peter Gow, na introdução de An Amazonian myth and its history que também examinou a tese como membro da banca - este é um dos raros trabalhos etnológicos sobre a relação entre a mitologia e a história. Destaca-se pela ênfase dada a dois temas evidenciados por Lévi-Strauss em História de Lince: o valor maléfico atribuído pelo pensamento indígena à simetria e o conseqüente "dualismo em perpétuo desequilíbrio" que marca seus mitos e instituições.

O tema central do livro, a relação entre índios e brancos, é abordado a partir de diferentes pontos de vista. Vilaça realizou pesquisa de arquivos para obter informações sobre a participação dos brancos no processo de "pacificação" dos Wari', que contou com dois protagonistas principais: o SPI e a MNTB o Serviço de Proteção ao Índio, e a Missão Novas Tribos do Brasil, respectivamente um órgão estatal e um protestante. Mais tarde, os católicos do CIMI, o Conselho Indigenista Missionário, começaram a atuar na área. A antropóloga entrevistou brancos e índios que presenciaram os primeiros contatos, momento em que remete à teoria do "equívoco" elaborada por Viveiros de Castro. Gravou um conjunto de mitos, no qual se vê com clareza a operação do pensamento relacional e posicional indígena. Nas palavras da autora, "mito e evento são relacionados porque são estruturalmente semelhantes, e não porque o evento é confundido com o episódio mítico" (:37). Valendo-se das análises de M. Sahlins e N. Wachtel, entre outros, Vilaça mostra algumas generalizações pan-americanas diante do "outro": "a visão wari' fica mais clara quando a contrastamos com a reação de outros povos nativos diante dos primeiros brancos, que foram percebidos em toda a sua estranheza, e associados a deuses que retornavam, a espíritos e a heróis míticos" (:257) e os pontos nos quais essa relação é especificamente wari': "humanos e animais aqui; deuses, heróis e espíritos acolá" (:258).

O objetivo do livro não é colocar os índios contra os brancos, no sentido de buscar a verdade de um lado. Trata-se de confrontar pontos de vista, de modo que se possam entender as razões de ambos, mas principalmente a diferença conceitual que os separa, sobretudo no que diz respeito à relação, ao corpo, à guerra, ao inimigo e à amizade. Dessa forma, a partir do idioma amazônico que coloca em relação a presa e o predador e que, como se pode notar no livro, às vezes têm significados diferentes quando vinculados por outros povos indígenas, as fronteiras que circunscrevem a etnologia são empurradas para além de si. Uma vez que um de seus desafios consiste em encontrar conceitos apropriados para lidar com povos que não operam, por exemplo, com o pensamento dialético, a etnologia mostra de fato que não é uma disciplina endogâmica e que dialoga, portanto, com outras disciplinas. 
O livro de Vilaça traz ainda uma significativa contribuição para o entendimento etnológico, porque realmente leva a sério o ponto de vista nativo. A antropóloga sabe o momento em que deve parar, não fazendo afirmações das quais não tem certeza, e também como se colocar, na medida em que suas intervenções jamais são verticais, condizentes, assim, com a antropologia sugerida por Roy Wagner e Viveiros de Castro, construída na relação entre o antropólogo e o nativo. Isto fica claro quando Vilaça discute a relação entre "natureza" e "cultura". Diz ela: "não basta, portando, adicionar uma dimensão histórica à velha noção de cultura; é necessário um deslocamento radical de perspectiva, só possível se adotarmos a perspectiva dos índios" (:512).

Desta forma, Vilaça não busca encontrar sentido naquilo que é exógeno ao povo que estuda. O fato não implica excluir o "de fora", na medida em que nesta socialidade são os Wari' que, a seu modo, introduzem o ponto de vista branco em seu benefício. Afinal, de acordo com a interpretação da autora dos episódios iniciais do contato: "os Wari' desejavam, antes de tudo, reconstruir sua própria sociedade, desorganizada pelos efeitos da invasão do seu território, e entenderam que os brancos os levariam a isso" (:30). Nesses episódios fica claro que a iniciativa para a participação no contato com outros subgrupos foi também dos Wari', embora aparentemente eles estivessem obedecendo a ordens: "como acontece ainda hoje, o que parece ser submissão é muitas vezes o modo que os Wari' encontraram de manipular, a seu favor, uma determinada situação. É como se eles fizessem questão de evitar qualquer tipo de conflito desnecessário, agradando aos brancos com o que parece ser respeito, somente porque sabem que gostam de ser tratados assim. Mas há um limite claro para esse tipo de atitude, quando os Wari' tomam a frente e decidem o que é melhor para eles, mesmo à revelia dos brancos" (:401).

Neste sentido, o livro está afiado com o debate etnológico contemporâneo que procura focalizar os aspectos conscientes da diacronia indígena, as chamadas teorias da "agência", sem se desvencilhar dos aspectos catastróficos resultantes do contato interétnico. Assim, deixa claro que a invasão do território, apesar de toda a sapiência wari', trouxe danos irrevogáveis. Afinal, como já haviam alertado Lévi-Strauss e Sahlins, "etnogênese e etnocídio não podem ser colocados em um mesmo plano" (:46). Por fim, o livro é uma homenagem aos Wari', na qual as futuras gerações poderão, com certeza, lê-lo para lá se encontrarem, e também se orgulharem dos seus antepassados. 